$7 \mathrm{C23}$

間葉系幹細胞の機械特性解析及び提示システムの構築

\title{
Mechanical feature analysis of mesenchymal stem cells and display system
}

\author{
学 ○清水 祐司 (大阪大学) 正 木原 隆典（大阪大学） \\ 非 Seyed Mohammad Ali Haghparast (大阪大学) \\ 非 弓場 俊輔 (産業技術総合研究所) 正 三宅 淳 (大阪大学)
}

Yuji SHIMIZU, Graduate School of Engineering Science, Osaka University, 1-3, Machikaneyama-cho, Toyonaka, Syunsuke YUBA, National Institute of Advanced Industrial Science and Technology

Key words : $\quad$ Mesenchymal Stem Cells, Atomic Force Microscopy, Haptic device

\section{1. 鼓直}

間葉系幹細胞（MSC）は中肧葉，非中胚葉系統への 多分化能を有する細胞であり，再生医療や組織工学に おいて応用利用されている。しかしながら MSC の生 理特性における調節機能は明確化されておらず，安全 性の確保や医療分野への実用化に向けて総合的な理解 が必要となっている，我々は，細胞の状態や運命に関 与しているとされる機械特性に着目し，高い分解能を 有する原子間力顕微鏡（AFM）を生体組織に応用する ことで直接的，非破壊的な機械特性の测定を行い， MSC の機能解析を進めている(1)(2). また, 力覚提示デ バイスを用いて，細胞機械特性の分析や，計測におけ る力学シミュレーションへの応用を目的とした細胞機 械特性提示システムの構築も行っている.

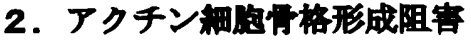

先行研究によると，機械特性は様々なアクチン細胞 骨格に支配されることが報告されている( ${ }^{(3)}$ 。我々は，

機械特性を解析することでアクチン細胞骨格の状態を 推し量ることが可能ではないかと考えて実験を進めて いる.そしてその上で,アクチン細胞骨格の形成と MSCの機能との関係性を考察し，新たな知見の獾得を 目指している．今回新たに，増殖能や細胞の高さとい った MSC における機能的な要素に関して, 調節を行 うアクチン骨格部位とその調節機能を調べ, 検討を行 った(2).

物理特性を支配するアクチン細胞骨格は図 1 が示す ように, Rho タンパクからのシグナルが下流のタンパ クへと経由していき形成される.アクチン細胞骨格の 機能を評価する為に，骨格系阻害剤である Y 27632

$(10 \mu \mathrm{M})$, blebbistatin $(5 \mu \mathrm{M}), \mathrm{C} 3$ Transferase $(20 \mathrm{ng} / \mathrm{mL})$, calyculin A $(0.15 \mathrm{nM})$, wiskostatin $(1 \mu \mathrm{M})$ を添加した. そして，アクチン骨格の形成を各過程で阻害すること で, MSC の機械特性, 増殖能, 形態等の変化を調へたた. また, 阻害㶡添加での培養期間は 2 日間である.

\section{AFM 睻定}

35mm ディッシュを使用し, rat MSC を播種後, 室温, 培地中で AFM 測定を行った. 細胞に対し $50 \mathrm{nN}, 10 \mu$ $\mathrm{m} / \mathrm{s}$ で図 2 (右) のように探針を押し込んでいく. 図 2 （左）は AFM 測定により得られた応力ー変位曲線を 示すフォースカーブで, 黒線で示されているのが押し 込み時のデータである. そして, 得られたフォースカ
ーブに対して式（1）に示した Hertz の理論式でフィッ ティングを行い，見かけのヤング率を算出する．測定 は核上部で行い, 1 条件につき 9points/cells で 10 細胞 測定し，中央值によって評価を行っている。

$$
F=\frac{E}{1-v^{2}} \frac{2 \tan \alpha}{\pi} \delta^{2}
$$

\section{4. 秎力党提示}

我々は、現在までの細胞機械特性の測定において、 弾性率が個々の細胞ごとにばらつき，幅広く分布する ことを確認してきた。また細胞弾性率のヒストグラム が対数正規分布を示すデータも獾得している（図 3). このように，細胞の機械特性は同一の試料（ドナー） であっても一意には決まらず，考察時や実験者間での 情報共有は困難である。 上記の問題を解決する為に, 我々は，近年細胞の解析システム等に応用されている 力覚提示デバイスを AFM 測定データと組み合わせる ことで，細胞機械特性の表現を試みた，また，細胞ご との弾性のばらつきも同時に表現している。

汎用性を考虑するため, AFM 測定において BAM コ 一ティングしたディッシュを用い，細胞を球状のまま 固定して测定を行った。また，測定におけるカンチレ バーはデータが乱れにくく，大量測定に有効なスフィ アタイプを使用した。対象の細胞には human MSC と HEK293を使用し，100points/cellsで 100 細胞測定し中 央值によって評価した。 得られたフォースカーブに対 して（2）に示した，球に対する Hertzの理論式でフィ ッティングを行い見かけのヤング率を算出した。

$$
F=\frac{4}{3} \delta^{\frac{3}{2}}\left(\frac{E}{1-v^{2}}\right) \sqrt{\frac{R_{1} R_{2}}{R_{1}+R_{2}}}
$$

全体のシステムフローを図 4 に示す. 前述した AFM 測定において得られた，細胞機械特性ヒストグラムの 中央值と分散の值をシステムに代入し, Box-Muller 法 を用いることで, 任意の対数正規分布に基づく乱数を 生成し, 細胞の弾性率として決定している。

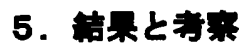

アクチン細胞骨格の形成阻害により，機械特性にお けるヤング率が低下, 高さの上昇が確認された.さら に, 細胞の ATP 総量を測ることで増殖能を確認したと 
ころ，形成阻害により上昇が見られた。また，阻害刱 添加時の細胞状態を共焦点顕微鏡で確認したところ, 核上部に渡って発達するアクチンキャップの破壊が確 認された. F-アクチンの性質や形態変化を考慮すると, アクチンキャップが破壊されたことにより，ディッシ ユ底面との間に存在していた内部張力が消失している と考えられる．以上のことから，MSCではアクチン細 胞骨格の中でもアクチンキャップが上記の特性の調節 を担っており、かつ増殖能に関しても調節を行ってい る可能性が示唆される。

構築した細胞力覚提示システムを図 5 に示す．用い た CPU は core i3 (2.53 GHz)，メモリは4GBである. また, 使用した力覚提示デバイスは Novint 社製, Falconである．実験者はハンドルを操作し，PC モニ タ上の細胞オブジェクトに操作点が接触することで 細胞の力覚を感じることが可能である.

\section{6. 赫}

本研究ではAFMを用いてMSCの機械特性を測定し， アクチン細胞骨格に着目した実験を行う中で浮かび上 がったアクチンキャップに関して, 増殖や形態に対す る調節機能の考察を行った. 今後, コルティカルアク チンなど他のアクチン細胞骨格にも焦点を当て，総合 的な細胞の理解に慗げていきたい。 また，細胞力覚提 示システムに関しても, 内部応力解析や稩胞マニピュ レーション等へ応用していきたいと考えている.

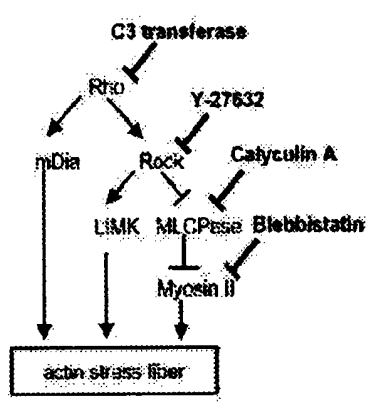

Fig.1 Schematics of effects

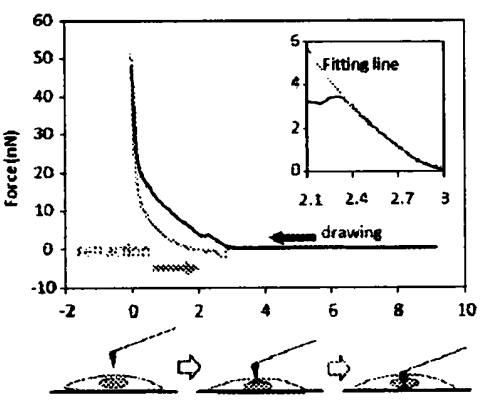

Fig.2 Measuring method by AFM

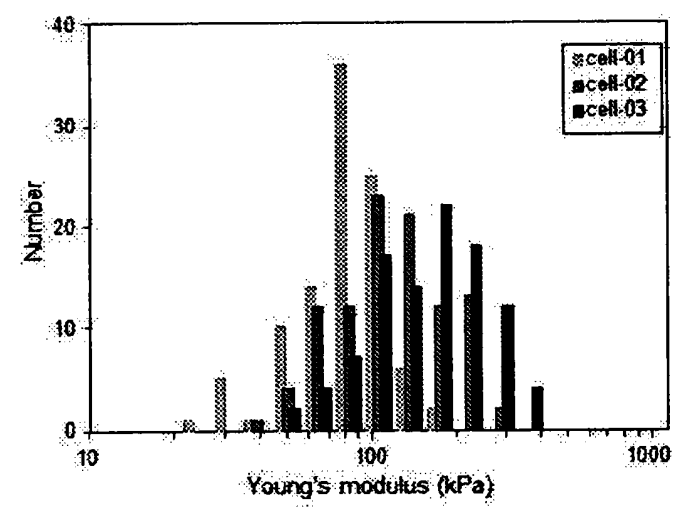

Fig.3 Young's Modulus Histogram
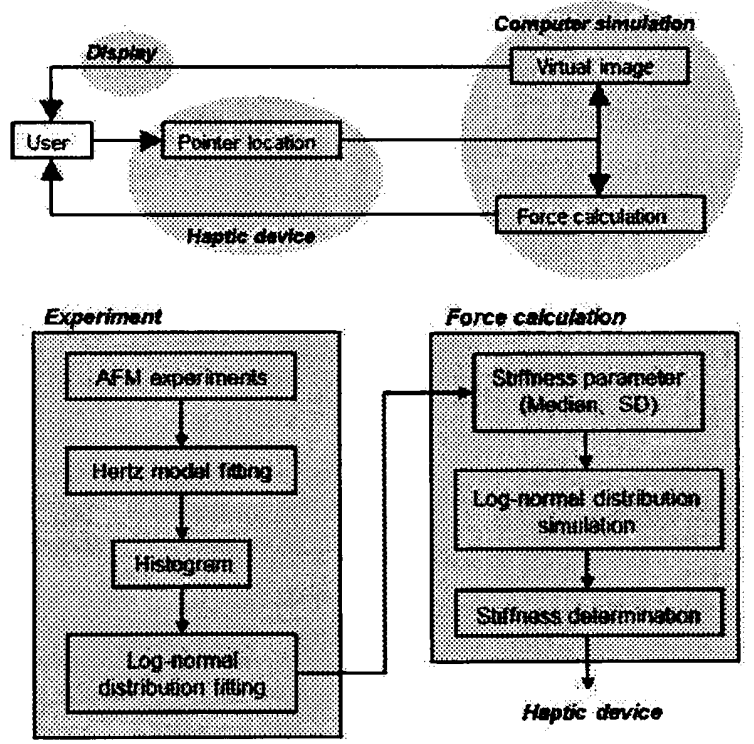

Fig.4 System flow

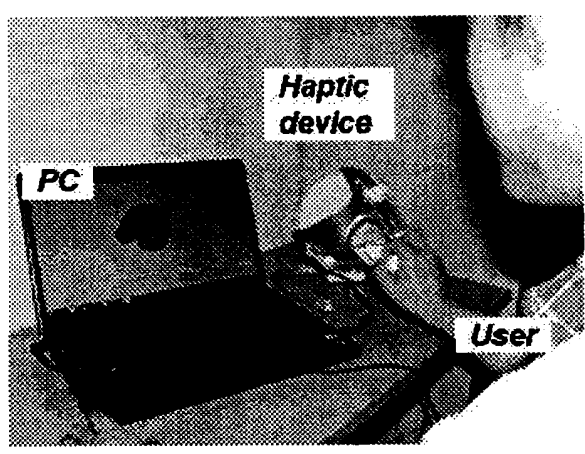

Fig.5 Cell Mechanical property display system

\section{孝文赫}

(1) T. Sugitate, T. Kihara, X-Y. Liu, J. Miyake, Mechanical role of the nucleus in a cell in term of elastic modulus, Curr.Appl. Phys. 9 (2009) e291-293.

(2) T. Kihara, S.M.A. Haghparast, Y. Shimizu, S. Yuba, J.Miyake, "Physical properties of mesenchymal stem cells are coordinated by the perinuclear actin cap", Biochemical and Biophysical Research Communications, No. 409 (2011), pp. 1-6.

(3) A.M. Collinsworth, S. Zhang, W.E. Kraus, G.A. Truskey, Apparent elastic modulus and hysteresis of skeletal muscle cells throughout differentiation, Am. J. Physiol. Cell Physiol. 283 (2002) C1219-1227. 